Title: Stoichiometric homeostasis of wetland vegetation along a nutrient gradient in a subtropical wetland. Understanding stoichiometric mechanisms of nutrient retention in wetland macrophytes.

Running Header: Wetland homeostasis

Paul Julian II ${ }^{1}$, Stefan Gerber ${ }^{2}$, Rupesh K. Bhomia ${ }^{2}$, Jill King ${ }^{3}$, Todd Z. Osborne ${ }^{4,2}$, Alan L. 6 Wright $^{1}$,

$7 \quad{ }^{1}$ University of Florida, Soil and Water Sciences Department, Ft. Pierce, FL 34945

8 *Corresponding Author: pjulian@ufl.edu; ORCID: 0000-0002-7617-1354

$9{ }^{2}$ University of Florida, Soil and Water Sciences Department, Gainesville, FL, 32611

${ }^{3}$ South Florida Water Management District, Water Quality Treatment Technologies, West Palm

11 Beach, FL, 33406

$12{ }^{4}$ University of Florida, Whitney Laboratory for Marine Bioscience, St Augustine, FL 32080

\title{
Abstract (limit 250 words)
}

Nutrient homeostasis relates ambient stoichiometric conditions in an environment to the stoichiometry of living entities of the ecosystem. In wetland ecosystems, vegetation can be a large, highly variable and dynamic sink of nutrients. This study investigated stoichiometric homeostasis of dominant emergent and submerged aquatic vegetation (EAV and SAV, respectively) within two treatment flow-ways (FW) of Everglades Stormwater Treatment Area 2 (STA-2). These FW encompass a large gradient in plant nutrient availability. The hypotheses of this study is that wetland vegetation is non-homeostatic relative to ambient nutrients and consequently nutrient resorption will not vary along the nutrient gradient. We developed a framework to investigate how vegetation uptake and resorption of nutrients contribute separately to homeostasis. Overall, the wetland vegetation in this study was non-homeostatic with respect to differential uptake of nitrogen $(\mathrm{N})$ vs. phosphorus $(\mathrm{P})$. Resorption evaluated for EAV was high for P and moderate for $\mathrm{N}$, resorption efficiency did not significantly vary along the gradient and therefore did not affect overall homeostatic status. Nutrient addition experiments may help to compensate for some of the limitation of our study, especially with respect to resolving the primary nutrient source (organic vs. inorganic sources, water vs. soil compartment) and nutrient utilization rates.

Keywords: Phosphorus, Everglades, resorption, sink strength, Stormwater Treatment Area 


\section{"The environment not only determines the conditions under \\ which life exists, but the organisms influence the conditions prevailing in their environment."}

- (Redfield 1958)

A tenet of ecological stoichiometry is that abundance of carbon $(\mathrm{C})$, nitrogen $(\mathrm{N})$, phosphorus $(\mathrm{P})$ or other elements is regulated by reciprocal interaction between organisms and their environment (Redfield 1958), and this relationship forms the underlying framework of stoichiometric homeostasis. In homeostatic organisms, nutrient stoichiometry is relatively fixed while nonhomeostatic organisms display flexibility with their respective nutrient stoichiometry. Homeostatic organisms regulate their elemental composition by adjusting bulk material uptake (i.e. ingestion rate), degree of food selectivity for growth and post-assimilation processes to regulate the acquisition of elements. Elemental uptake by non-homeostatic organisms, is mostly controlled by supply (i.e. nutrient availability) rather than demand (i.e. relative growth rate) with limits to nutrient loss processes such as excretion in animals and senescence in plants (Killingbeck 1996; McGroddy et al. 2004).

The concept of stoichiometric homeostasis was formulated as a means to understand patterns of $\mathrm{C}, \mathrm{N}$ and $\mathrm{P}$ in zooplankton to evaluate food quality and nutrient recycling (Jotaro Urabe et al. 1995; Elser and Urabe 1999; J. Urabe and Sterner 2001; Sterner and Elser 2002; Malzahn et al. 2007; Mulder 2007; Mulder and Bowden 2007). Later, the concept has been broadened to understanding food web stoichiometric dynamic (Persson et al. 2010), specific stream food web stoichiometric interactions (Feijoó et al. 2014), resource dependence of bacteria (Makino et al. 2003), and grassland community level responses to climate change ( $\mathrm{Gu}$ et al. 2017). The stoichiometric homeostasis conceptual model is thus of particular interest with respect to nutrient 
55 enrichment and biotic uptake processes due to selective uptake of nutrients during nutrient

56 enriched conditions (Sterner and Elser 2002; Small et al. 2009).

57 Stoichiometric flexibility or homeostatic plasticity (i.e. non-homeostasis) can manifest across

58 different spatial scales from organisms to ecosystems. At the organismal level, stoichiometric

59 flexibility can occur through changes in nutrient allocation to tissue types or biochemical

60 changes in cellular composition (Sistla and Schimel 2012; Rivas-Ubach et al. 2012). At the

61 ecosystem level, changes in stoichiometry can occur through changes in ecosystem composition

62 including changes in consumer and producer species composition and encroachment of invasive

63 species (Sistla et al. 2015). Therefore, stoichiometric flexibility is driven by species-specific

64 nutrient biomass storage, physiological plasticity, interspecific competition and the variability in

65 nutrient supply versus demand (Elser et al. 2010; Sardans et al. 2012; Sistla et al. 2015).

66 Heterotrophs (i.e. herbivores) are constantly faced with stoichiometric mismatch but can combat

67 it to maintain constant elemental composition through strategies of selective consumption or

68 elimination of particular elements (Filipiak and Weiner 2014). Meanwhile, autotrophs such as

69 plants have internal mechanisms to continue building up biomass and stoichiometric composition

70 through selective uptake and internal nutrient retention processes such as nutrient resorption.

71 Nutrient resorption, is a process in which nutrients are withdrawn from senescing leaves before

72 abscission to be used for new growth or stored for later use (Van Heerwaarden et al. 2003). It is

73 assumed to be one of the most important strategy used by plants to conserve nutrients

74 (Rejmánková 2005).

75 Most nutrient resorption studies focus on terrestrial (upland) evergreen, deciduous, forb and

76 graminoid species (Killingbeck 1996; Aerts and Chapin 1999; Van Heerwaarden et al. 2003;

77 Peng et al. 2016) with only few studies investigating wetland plant species (Miao 2004; 
Rejmánková 2005; Rejmánková and Snyder 2008). Rejmánková (2005) observed relatively high nutrient resorption efficiencies for wetland plant species including cattail (Typha domingensis) for both $\mathrm{N}$ and $\mathrm{P}$ across a variety of nutrient limiting conditions. In a nutrient addition study, Rejmánková and Snyder (2008) observed high N and P resorption across P-limiting conditions in cattail and spike rush (Eleocharis spp.). Meanwhile, Miao (2004) observed high P and low N resorption in two wetland macrophytes, sawgrass (Cladium jamaicense) and cattail in P-limiting conditions. These studies suggest that $\mathrm{P}$ resorption is typically high regardless of $\mathrm{P}$ limitation status while $\mathrm{N}$ resorption can vary depending on $\mathrm{N}$ availability and can contribute significantly to stoichiometric homeostatic.

87 While limited to a few studies, prior work suggest that plants range in their degree of homeostasis from very weak to non-homeostatic (Yu et al. 2011; Gu et al. 2017). However, these studies focused on terrestrial grasses and shrub species and not wetland plant species distributed along a nutrient gradient. In contrast to upland ecosystems biogeochemical processes in wetlands are influenced by specific non-biotic (inundation, geochemical precipitation of nutrients) and biotic (i.e. plant, periphyton, algae, etc.) interactions that can alter the oxidation-reduction and pH environment (Reddy and DeLaune 2008; Kadlec and Wallace 2009). These interactions pose additional challenges to producers with respect to nutrient supply and demand. Earlier work in wetlands shows a decrease of plant $\mathrm{P}$ concentration with decreasing ambient $\mathrm{P}$ concentration (Richardson et al.,1990, Julian et al., 2019). This suggests non-homeostatic behavior although

97 the author did not test for homeostasis. Therefore, the first objective of this study was to evaluate the strength of stoichiometric homeostasis in dominant wetland species along a nutrient gradient 99 in two flow-ways (FW) within the Everglades Stormwater Treatment Areas (STAs; Fig. 1). 100 These treatment wetlands use emergent and submerged aquatic vegetation (EAV and SAV, 
101 respectively) to remove nutrients via biotic uptake. Prior studies of nutrient resorption with

102 respect to emergent aquatic vegetation (EAV) suggest that EAV species use both "conservation

103 of use" and "enhanced acquisition" of P to fulfill nutrient demand in P-limited systems (Miao

104 2004; Rejmánková 2005; Rejmánková and Snyder 2008). Moreover these studies indicate that

105 EAV utilize the "conservation of use" strategy making resorption dependent upon nutrient

106 availability. Sterner and Elser (2002) suggest that autotrophic organism's stoichiometry is not

107 solely dictated by nutrient availability but also biophysical, physiological adaptions and optimal

108 nutrient utilization. The first objective of this study was to determine the degree of stoichiometric

109 homeostasis of wetlands plants along a strong nutrient gradient with the hypothesis that EAV and

110 SAV are generally homeostatic relative to the ambient environment due to biological adaptions

111 in nutrient uptake, utilization and storage. The second objective of this study was to evaluate

112 nutrient resorption dynamics of EAV species within the treatment wetland and with the

113 hypotheses that resorption efficiency (RE) significantly differs as a function of nutrient

114 limitation status (i.e. $\mathrm{N}$ or $\mathrm{P}$ limitation) and the degree of stoichiometric homeostasis observed

115 among wetland plants is caused by differences in nutrient resorption.

\section{Methods}

118 Study Area

119 A total of six Everglades STAs with an approximate area of $231 \mathrm{~km}^{2}$ are located south of Lake 120 Okeechobee in the southern portion of the Everglades Agricultural Area (Fig. 1). The Everglades

121 STAs are established on land which earlier had natural wetlands and/or agricultural farmlands

122 under sugarcane production. The primary source of inflow water to the STAs is agricultural

123 runoff originating from approximately $284 \mathrm{~km}^{2}$ of farmland upstream. Everglades STA treatment 
124 cells or FWs are comprised of a mixture of EAV and SAV communities in several configurations

125 including EAV and SAV treatment cells arranged in parallel or in series (Chen et al. 2015).

126 Stormwater Treatment Area-2 (STA-2) has been in operation since June 1999 with an effective

127 treatment area of approximately $63 \mathrm{~km}^{2}$ divided into eight treatment cells. This study was

128 conducted in two cells, FWs 1 and 3 . The vegetative community of FW 1 is comprised

129 predominately of EAV vegetation including Typha domingensis Pers. (cattail) and Cladium

130 jamaicense Crantz (sawgrass) while FW 3 is dominantly SAV including Chara spp. (muskgrass),

131 Potamogeton spp. (pondweed) and Najas guadalupensis Spreng (southern naiad) with

132 approximately a quarter of the FW occupied by EAV species. Furthermore, prior to STA-2

133 construction FW 1 was a historic natural wetland while approximately three-quarters of FW 3

134 was previously farmed and is now managed as an SAV system (Juston and DeBusk 2006).

135 Data Source

136 Data used in this study were collected by South Florida Water Management District (SFWMD)

137 and University of Florida as a part of a larger project within the overall SFWMD's Restoration

138 Strategies Science Plan to evaluate performance and optimization of the Everglades STAs (South

139 Florida Water Management District 2013). Data from the Science Plan study: Evaluation of P

140 Sources, Forms, Flux and Transformation Processes in the STAs was used for this investigation

141 (UF-WBL 2017; Villapando and King 2018). We used weekly surface water grab samples

142 collected at monitoring locations along a nutrient gradient from inflow to outflow within FWs 1

143 and 3 in STA-2 to characterize changes in nutrient concentrations during prescribed/semi-

144 managed flow events (Fig. 1). Samples were collected just under the water surface at 10-15 cm

145 depth during prescribed flow events that cycled through various flow/no-flow sequences for FWs

1461 and 3. For this study we used the water column parameters total P (TP), total N (TN), and 
147 dissolved organic C (DOC) (Villapando and King 2018). In the Everglades system, the surface

148 water organic C pool is predominately composed of the DOC fraction with low particulate OC

149 concentrations (Julian et al. 2017), therefore total OC is assumed to be equivalent to DOC

150 concentrations. We also made use of soil samples collected along the flow transects twice during

151 the dry and wet seasons between 2015 and 2016 and analyzed for TP, TN, and TC. Vegetation

152 tissue were collected from live and senescent above-ground biomass (AGB) vegetation in FW 1

153 while only live-AGB was sampled from FW 3 at the end of the 2015 (November 2015) and 2016

154 (September 2016) wet seasons. The ability to collect senescent SAV is extremely difficult as it 155 decomposes rapidly and becomes part of the "litter" immediately, therefore no samples were 156 available for analysis. Vegetation samples were collected from inflow, mid and outflow regions 157 of the FWs within close proximity to the surface water and soil monitoring locations (Fig. 1). 158 Only co-located surface water, soil and vegetation sampling locations were considered for this 159 study (Fig. 1). Nutrient content of vegetation was determined from dried ground and 160 homogenized samples. For conducting analyses and summary statistics, data reported as less than method detection limit (MDL; Table S1) were assigned a value of one-half the MDL, unless

162 otherwise noted.

164 We categorized foliar TN:TP molar ratios for EAV along the FW 1 transect into potential N165 limitation (molar TN:TP<14), potential $\mathrm{N}$ and $\mathrm{P}$ co-limitation $(14<\mathrm{TN}: \mathrm{TP}<16)$ and $\mathrm{P}$ 166 limitation (TN:TP > 16). For SAV along the FW 3 transect we categorized foliar TN:TP molar 167 ratios into potential N-limitation (TN:TP < 27) and potential P-limitation (TN:TP > 27). These 168 potential nutrient limiting categories were consistent with other EAV studies (Koerselman and 169 Meuleman 1996; Rejmánková 2005) and SAV studies (Duarte 1992; Fernández-Aláez et al. 
1999). We compared nutrient limitation categories between FW regions (i.e. inflow, mid and

171 outflow) using chi-squared (RxC) analysis.

172 We evaluated $\mathrm{P}$ and $\mathrm{N}$ resorption efficiency ( $R E_{T P}$ and $\mathrm{RE}_{\mathrm{TN}}$, respectively) along the $\mathrm{FW} 1$ 173 transect by comparing living $\left(\mathrm{X}_{\mathrm{GR}}\right)$ to senescent $\left(\mathrm{X}_{\mathrm{SEN}}\right)$ EAV AGB nutrient tissue concentrations.

174 Resorption efficiency was estimated using Eq. 1, consistent with prior studies (Killingbeck 1996;

175 Reed et al. 2012).

$$
R E_{x}=\frac{X_{G R}-X_{S E N}}{X_{G R}} \times 100 \quad \text { Eq. } 1
$$

177 We compared $\mathrm{RE}_{\mathrm{TP}}$ and $\mathrm{RE}_{\mathrm{TN}}$ values between P-limiting categories identified above for aquatic 178 vegetation type specific foliar TN:TP molar ratios using the Kruskal-Wallis rank sum test. 179 Resorption efficiency values for each site was compared with fractional distance from inflow 180 using Spearman's rank correlation. We also compared $\mathrm{RE}_{\mathrm{TP}}$ and $\mathrm{RE}_{\mathrm{TN}}$ between stations using 181 Dunn’s multiple comparison rank sum test ('dunn.test’ R package; Dinno 2015).

182 We characterized the strength of vegetation TN:TP total stoichiometric homeostasis $\left(\mathrm{H}_{\mathrm{T}}\right) \mathrm{using}$ 183 the homeostasis coefficient (Eq. 2). Equation 2a is a log-linear model where $y$ is the live-AGB 184 TN:TP molar ratio, $x$ is the TN:TP molar ratio of the resource, $c$ is a constant that determines the 185 intercept and $1 / H_{T}$ is the slope of the model between the log transformed ratios $x$ and $y$ and 186 represents the strength of homeostatic maintenance of nutrient ratios within the consumer 187 biomass. Reorganizing Eq. 2a to solve for $\frac{1}{H_{T}}$ we get Eq. 2 b.

$$
\log (y)=\log (c)+\frac{\log (x)}{H_{T}} \quad \text { Eq. } 2 \mathrm{a}
$$




$$
\frac{1}{H_{T}}=\frac{\log (y)-\log (c)}{\log (x)} \quad \text { Eq. } 2 \mathrm{~b}
$$

Hypothetically, values of $1 / H_{T}$ range between zero and one, with values approaching one

190

191

192

193

194

195

196

197

198

199

200

201

202

203

204

205

206

207

indicating a non-homeostatic relationship and values approaching zero signifying consumer-

resource homeostasis. The degree of homeostasis was defined consistent with prior studies

(Makino et al. 2003; Persson et al. 2010; Feijoó et al. 2014) as the following:

1. $0.00<1 / H_{T}<0.25:$ Homeostatic

2. $0.25<1 / H_{T}<0.50$ : Weakly-Homeostatic

3. $0.50<1 / H_{T}<0.75$ : Weakly Non-Homeostatic

4. $0.75<1 / H_{T}<1.00:$ Non-Homeostatic

The stoichiometric homeostasis coefficient is an integrated metric to relate the ambient environment's stoichiometry to that of the vegetation biomass. Moreover $\mathrm{H}_{\mathrm{T}}$ can be used to determine if the observed variation in the biota stoichiometry is the result of physiological adjustments or reflects species-specific turnover (Elser et al. 2010). To assess the homeostatic relationship of the vegetation relative to the ambient environment, N:P ratios of resource pools were compared to the N:P ratios of AGB for each vegetation community. The communities' uptake pathways differ between SAV and EAV - SAV primarily assimilate nutrients through the water column while EAV obtain nutrients from the soils via soil solution (Richardson and Marshall 1986; Reddy et al. 1999; Dierberg et al. 2002). Therefore, we compared AGB N:P values of both EAV and SAV to surface water and soil N:P values (denoted as $\mathrm{x}$ in Eq. 2). Due to offset sampling times, soil and AGB data were paired only when samples were collected within six months of each other for each site. Site-specific surface water mean TN:TP values 
209

210

211

212

213

214

215

216

217

218

219

220

221

222

223

224

225

226

227

228

229

230

231

during this six-month timeframe were paired with AGB values. Biota TN:TP molar ratios were identified as each respective vegetation type live-AGB TN:TP molar ratio (y in Eq. 2). We used the Theil-Sen single median linear model ('mblm' package; Komsta 2013) to evaluate biota and resource TN:TP molar ratios to estimate $\mathrm{c}$ and $1 / \mathrm{H}_{\mathrm{T}}$ in Eq. 2 .

To evaluate the overall homeostatic versus non-homeostatic status among vegetation within a FW, we evaluated the slope of the mblm linear models for each FW to determine if the slope was significantly different from 0.50 using the One-Sample Wilcoxon rank signed test. This test is similar to the t-test slope comparison method identified by Zar (2010) for parametric linear models. The 0.50 threshold was selected as it is the criterion that differentiates homeostasis from non-homeostasis (see above).

We also characterized the degree of stoichiometric homeostasis with respect to differential resorption similar to the approach for stoichiometric homeostasis $\left(\mathrm{H}_{\mathrm{T}}\right)$ above. Resorption efficiency homeostasis $\left(\mathrm{H}_{\mathrm{RE}}\right)$ was evaluated for EAV to assess whether RE changes with respect to the ambient environment. We used mblm to evaluate the relative loss of nutrients after resorption $\left(y_{R E}\right)$ relative to resource TN:TP $(\mathrm{x})$ where the slope of linear model is $1 / \mathrm{H}_{\mathrm{RE}}$. The relative loss of nutrients after resorption $\left(y_{R E}\right)$ or the senescence efficiency is represented by Eq. 3. In the supplementary material we develop the framework to evaluate how resorption contributes to homeostasis, the resulting relationship is given in Eq. 4 which is very similar to Eq. 2. The subtraction of one on the left-hand side in Eq. 4 originates from the fact that this equation states the vegetation's effort into homeostasis via resorption, where zero would yield an effort to maintain full homeostasis and negative one would mean that there is no homeostasis with respect to resorption (Supplemental Material). The regression constant $\mathrm{c}$ is different than in Eq. 2, but is in both cases irrelevant to the calculation of stoichiometric homeostasis. 


$$
y_{R E}=\frac{\left(1-R E_{T P}\right)}{\left(1-R E_{T N}\right)} \quad \text { Eq. } 3
$$

$$
\frac{1}{H_{R E}}-1=\frac{\log \left(y_{R E}\right)-\log (c)}{\log (x)} \quad \text { Eq. } 4
$$

235 In the supplemental material, we have developed a framework which can relate the two major 236 pathways for homeostasis (resorption and uptake) with each other. Total homeostasis $\left(H_{T}\right.$; Eq. 2)

237 and the vegetation's effort to maintain homeostasis can then be partitioned into contributions 238 from resorption (Eq. 4) and uptake:

$$
\left(1-\frac{1}{H_{R E}}\right)+\left(1-\frac{1}{H_{U}}\right)=\left(1-\frac{1}{H_{T}}\right) \quad \text { Eq. } 5
$$

240 All statistical operations were performed with R@ (Ver 3.1.2, R Foundation for Statistical

241 Computing, Vienna Austria), unless otherwise stated all statistical operations were performed

242 using the base R library. The critical level of significance was set at $\alpha=0.05$.

\section{Results}

245 Surface water DOC, TN concentrations, DOC:TP and TN:TP molar ratios were overall higher in

246 FW 3 (SAV) while surface water TP concentrations and DOC:TN molar ratios were higher in

247 FW 1 (EAV) (Table 1). Soil organic matter, as indicated by loss-on-ignition, was greater in FW1 
248

249

250

251

252

253

254

255

256

257

258

259

260

261

262

263

264

265

266

267

268

269

while soil Ca concentrations were greatest in FW3 soils indicating that FW1 soil is more organic (i.e. peat) and FW3 more mineral (i.e. marl). In addition to qualitative differences between soil composition, FW1 soils were generally more enriched with TP and TN. Among carbon and nutrients, soil TP had the highest coefficient of variation between and within sites and FWs with an overall coefficient of variation of $48 \%$. Overall, FW 1 exhibited the highest coefficient of variation for soil TP with $40 \%$ spatial and temporal variability (Table 1).

\section{Tissue Stoichiometry}

Live AGB TN : TP molar ratios were greatest in FW 3 (Table 1 and Fig. 2). Vegetation from both FWs spanned their respective potential $\mathrm{N}$ and P-limiting conditions with most values above the P limits identified for EAV (TN:TP>16) and SAV (TN:TP>27) communities (Table 1 and Fig. 2). Furthermore, AGB TC:TN values were greater in FW 1, ranging from 19.3 to 82.8 whereas FW 3 ranged from 7.5 to 23.7 suggesting the potential for N-limitation in FW 1 (Fig. 2). AGB TN:TP values were significantly different along the FW 1 transect $\left(\chi^{2}=19.4, \mathrm{df}=4, \rho<0.01\right)$ characterized by strong nutrient decline along the FW from inflow to outflow. Several values below the TN:TP value of 14 (indicating $\mathrm{N}$ limiting conditions) were observed, most of which occurred at the Inflow and Mid regions of the FWs and all values above the P-limiting criteria occurred in the Outflow region. Meanwhile, nutrient limiting conditions were not significantly different along the FW 3 flow path $\left(\chi^{2}=5.6, \mathrm{df}=2, \rho=0.06\right)$ with the majority of the TN:TP values greater than 27 indicating potential P-limitation, and four samples less than 27 occurring in the Inflow and Mid regions of FW. 
271 Changes in AGB stoichiometry occurred concurrent with changes in both surface water and soil

272 resource stoichiometry pools (Fig. 3). Log-log models comparing vegetation N:P to resource N:P 273 resulted in slopes significantly different from zero (Table 2) with varying levels of fit. The model

274 with the lowest $\mathrm{R}^{2}$ was the SAV (FW 3) N:P to surface water N:P (Table 2). The relationship 275 between the vegetation and the ambient environment depends on which resource pool was 276 considered and thereby where each vegetation type falls on the $\mathrm{H}_{\mathrm{T}}$ continuum. For instance,

277 EAV is weakly homeostatic if the water column is considered to be the major nutrient source and 278 non-homeostatic if nutrients are assumed to be taken up from the soil (Fig. 4 and Table 2). The 279 homeostasis coefficients, $1 / \mathrm{H}_{\mathrm{T}}$, when considering soil as a potential resource pool, were 280 significantly greater than 0.5 for $\operatorname{EAV}(\mathrm{V}=153870, \rho<0.01)$ and $\operatorname{SAV}(\mathrm{V}=14455, \rho<0.01)$ 281 indicating that vegetation is non-homeostatic with respect to soil TN:TP (Fig. 4). In fact, the 282 homeostasis coefficient $1 / \mathrm{H}_{\mathrm{T}}$ for EAV sourcing nutrient from soil is greater than 1 . Meanwhile, $2831 / \mathrm{H}_{\mathrm{T}}$ values when considering surface water as a potential resource pool were significantly less 284 than 0.5 for EAV $(\mathrm{V}=53539, \rho<0.01)$ and not significantly different for $\operatorname{SAV}(\mathrm{V}=15452, \rho=0.36)$ 285 suggesting EAV and SAV with respect to surface water is weakly homeostatic to weakly non286 homeostatic, respectively (Fig. 4).

289 A total of 38 plant tissue samples were collected during the vegetation sampling events where 290 both live and senesced AGB were available from EAV (FW1). Cattail comprised most of the 291 species collected $(\mathrm{N}=36)$ with one sample each from lily and sawgrass. The estimated mean 
$292 \mathrm{RE}_{\mathrm{TP}}$ value for cattails was $74 \pm 2 \%(\mathrm{~N}=36)$, with the individual $\mathrm{RE}_{\mathrm{TP}}$ values for water lily and 293 sawgrass being $70 \%$ and $77 \%$, respectively (Table 3). Along FW 1, cattail RE $\mathrm{TP}_{\mathrm{TP}}$ wot

294 significantly correlated with fractional distance downstream along the resource gradient $\left(\mathrm{r}_{\mathrm{s}}\right.$ $295=0.21, \rho=0.22)$ or statistically different between sites $\left(\chi^{2}=3.9, \mathrm{df}=2, \rho=0.14\right)$. The estimated 296 mean $\mathrm{RE}_{\mathrm{TN}}$ value for cattails was $32 \pm 3 \%(\mathrm{~N}=36)$, with $\mathrm{RE}_{\mathrm{TN}}$ values for just sawgrass observed 297 to be $2.3 \%$ (Table 3). Much like $R E_{T P}$, cattail $R_{T N}$ was not significantly correlated with 298 fractional distance downstream $\left(r_{s}=-0.04, \rho=0.84\right)$ or statistically different between sites $\left(\chi^{2}=\right.$ $2992.9, \mathrm{df}=2, \rho=0.23$ ). Both TP and TN RE did not significantly differ between nutrient limitation 300 categories as indicated by tissue TN:TP molar ratios $\left(\chi^{2}=0.74, \mathrm{df}=2, \rho=0.70\right.$ and $\chi^{2}=0.38, \mathrm{df}=2$, $301 \rho=0.83$, respectively).

\section{Partitioned Contributors to Stoichiometric Homeostasis}

304 Senescence efficiency ranged from $9 \%$ to $76 \%$ for $\mathrm{P}$ and $44 \%$ to $98 \%$ for $\mathrm{N}$ in cattail along $\mathrm{FW}$ relationship.

\section{Discussion}


314 All organisms are faced with the challenges of acquiring sufficient energy and nutrients, with

315 most organisms dealing with a mixture of these resources in the environment that is imbalanced

316 relative to their requirements. Resource constraints and imbalances can alter individual species

317 strategies, population dynamics, inter-specific competition for resources, and even influence key

318 ecosystem processes (Frost et al. 2005). Ultimately, stoichiometric homeostasis is largely

319 controlled by a set of key physiological processes that regulate uptake, incorporation and

320 eventual release of nutrients (Sterner and Elser 2002). These processes must contend with what

321 is available in the ambient environment and can manifest as stoichiometric mismatches and lead

322 to nutritional imbalances. We used the concept of stoichiometric homeostasis to evaluate the

323 degree to which plants in a wetland ecosystem respond to variations in nutrient supply. The

324 dominant features of the variable nutrient supply in our system were both a decreasing P load

325 (i.e. uptake during transport) and a diminishing resource gradient (i.e. soil nutrient concentration)

326 with distance from inflow to outflow of two treatment wetland FWs.

327 Neither of the two types of vegetation (EAV and SAV) in the two studied FWs evaluated here

328 displayed clear homeostatic behavior, in that N:P stoichiometry of AGB remained independent

329 of the N:P stoichiometry of the resources (i.e. soil or water column nutrient pools). Considering

330 the water column as the resource supply, both EAV and SAV displayed weakly homeostatic to

331 weakly non-homeostatic behavior, respectively. However, if soil is considered as the resource

332 pool, EAV and SAV are considered weakly to strongly non-homeostatic, respectively. Generally,

333 EAV use nutrients from the soil while SAV obtains nutrients from the water column.

334 Early in the development of stoichiometric homeostasis theory it was hypothesized that

335 photoautotrophs (i.e. algae and plants) were considered to have very weak stoichiometric

336 homeostasis $(0.25<1 / \mathrm{H}<0.50)$, suggesting that they do not strongly regulate biomass 
stoichiometry relative to the ambient environment due to luxury uptake of nutrients (Sterner and

Elser 2002; Reddy and DeLaune 2008; Elser et al. 2010). Since development of the concept, however, several studies have suggested that plants can range from weakly homeostatic to nonhomeostatic $(1 / \mathrm{H}>0.50)$ (Sterner et al. 1998; Elser et al. 2000; McGroddy et al. 2004; Güsewell 2004). Moreover, Demers et al. (2007) suggested that the relationship between external nutrient concentrations (i.e. soil and water column) and foliar tissue nutrient concentrations in aquatic macrophytes indicates a weakly non-homeostatic to non-homeostatic relationship similar to other terrestrial and algae species. This conclusion was confirmed in our study from treatment wetlands of south Florida which received high inputs of $\mathrm{P}$ as agricultural runoff.

A very important aspect of stoichiometric homeostasis is the proper pairing of resource to organism along a trophic chain as this affects the efficiency of trophic transfer of. Theoretically, $1 / H$ values range from zero to one. However, values can exceed one, and in this study, a homeostasis value greater than one was observed when comparing soil and EAV N:P. This is manifested by a disproportionate increase in AGB N:P with increasing soil N:P. In a review of

351 stoichiometric homeostasis, Persson et al. (2010) reported several studies with $1 / H$ values 352 greater than one. As suggested by Smalley et al. (2003), it is possible that non-inhibitory light

353 levels leading to high $\mathrm{C}$-fixation and greater biosynthetic need for $\mathrm{N}$ and $\mathrm{P}$ to use the additional $354 \mathrm{C}$ could lead to $1 / H_{N: P}>1$. EAV, and especially cattails, are generally not growth-limited by 355 light due to its tall structure above the water and broad leaves. Therefore, it is possible that EAV 356 can respond by disproportionally directing $\mathrm{N}$ use towards building other cellular machinery to 357 optimize nutrient use and functionality. An alternative mechanism may be that, in this P-limited 358 system, $\mathrm{P}$ acquisition becomes increasingly difficult as $\mathrm{N}: \mathrm{P}$ increases because $\mathrm{P}$ is stored in 359 increasingly inaccessible forms within the resource pool. 
360

361

362

363

364

365

366

367

368

369

370

371

372

373

374

375

376

377

378

379

380

381

382

It is possible that both vegetation types (EAV and SAV) take up nutrients from soil and water. For EAV, homeostatic behavior appears stronger if the nutrient resource is assumed to come from the soil rather than water column (Fig. 4). By the same token, homeostasis for SAV is stronger if nutrients are assumed to be supplied from the water column (Fig. 3), although the difference between the homeostasis coefficients for SAVs is decidedly lower compared to EAVs (Fig 6). This may in turn partially be explained by lower variability in $\mathrm{N}: \mathrm{P}$ ratios in EAV compared to SAV, which in turn suggests less flexible N:P ratios and thus stronger homeostasis in EAV.

As expected, stoichiometric mismatches were observed within our study system where resource (i.e. soil or water column) N:P were greater than that of the AGB N:P (Table 1). Both soil and water resource pools differed between FWs with water having a greater variability than that of soil. This is notable as a strong soil P gradient is apparent along the FW (Osborne et al, In Prep), potentially indicating changes in P-availability and the physiological limitation to use the existing P-pool. This limitation has been noted in prior studies where uptake is lower in treatments with higher available P (Shaver and Melillo 1984; Craft et al. 1995). Variability and differences in the relative ratio of resources to consumer indicate that vegetation types access available nutrient pools differently. In lake ecosystems, Rattray et al. (1991) determined that SAV take up nutrients from the water column. However, other studies have demonstrated that, while SAV are involved in active uptake of nutrient from the water column, it also modifies the physical environment through photosynthesis and respiration causing the precipitation of $\mathrm{P}$ to mineral bound P compounds (Dierberg et al. 2002; Reddy and DeLaune 2008). Submerged macrophyte systems invoke $\mathrm{P}$ mineralization by inadvertently manipulating $\mathrm{C}$ (via dissolved inorganic $\mathrm{C}$ ) and $\mathrm{pH}$ through respiration and photosynthesis. In $\mathrm{FW} \mathrm{3,} \mathrm{pH} \mathrm{values} \mathrm{ranged} \mathrm{from} 6.9$ 
to 10.4 (Julian et al. 2019) and, combined with a high mineral content environment, can lead to coprecipitation of $\mathrm{P}$ with $\mathrm{CaCO}_{3}$ (Boyer and Wheeler 1989)(Table 1). Much like their emergent relatives, rooted SAV can also obtain nutrients from the soil but to a lesser degree (Brix 2003; Dhote and Dixit 2009). Stoichiometric mismatch in producer-consumer (i.e. detritusinvertebrate) systems, typically identify nutritional deficiency in food sources (Filipiak and Weiner 2014, 2017; Filipiak 2016). In this case stoichiometric mismatch is indicative less of nutritional deficiency but more of limitation in nutrient utilization and availability as well as the potential for plant-environment nutrient feedbacks discussed above. Regardless of the stoichiometric mismatch observed, we still observe predominantly non-homeostatic responses by vegetation across $\mathrm{N}$ to $\mathrm{P}$-limiting conditions for both FWs despite being predominant $\mathrm{P}$. Generally, plant species respond to changes in nutrient available nutrients through the storage and recycling of nutrients, ultimately shifting absolute and relative tissue nutrient concentrations in a way suggesting a non-homeostatic relationship with their ambient environment (Güsewell and Koerselman 2002; Güsewell et al. 2003; Rejmánková et al. 2008). The resorption of nutrients from senescing tissues is often considered a strategy in nutrient-limiting conditions to conserve scarce nutrients (Aerts and Chapin 1999; Rejmánková et al. 2008). Nutrient resorption efficiency of EAV observed in this study (Table 3) (Table 1) is consistent with values observed for aquatic macrophytes by studies elsewhere (Miao 2004; Rejmánková 2005). Rejmánková (2005) evaluated resorption of macrophyte species from several wetlands across a broad spatial 402 distribution and observed that cattail achieved a maximum $\mathrm{RE}_{\mathrm{TP}}$ of approximately $80 \%$ while the 403 study average was 70\%. Rejmánková (2005) also observed that $\mathrm{RE}_{\mathrm{TP}}$ was significantly greater in 404 P-limiting conditions. Meanwhile, Miao (2004) evaluated RE $\mathrm{TP}_{\mathrm{P}}$ of two aquatic macrophytes in a 405 mesocosm setting with two-nutrient treatment regimens broadly defined as enriched (high 
406

407

408

409

410

411

412

413

414

415

416

417

418

419

420

421

422

423

424

425

426

427

428

nutrient availability) and unenriched (low nutrient availability). Miao (2004) observed $\mathrm{RE}_{\mathrm{TP}}$ ranging from 69 to $82 \%$ for sawgrass and 61 to $71 \%$ for cattail between treatments with no treatment effect, indicating that ,despite available nutrient conditions, resorption remains relatively high. Miao (2004) also observed $\mathrm{RE}_{\mathrm{TN}}$ values ranging from 33 to $45 \%$ between cattail and sawgrass species with no significant differences between treatment or species. In our study, $\mathrm{RE}_{\mathrm{TP}}$ or $\mathrm{RE}_{\mathrm{TN}}$ was not significantly different along the flow way despite potential shifts in relative $\mathrm{N}$ or P-limitation as indicated by foliar TN:TP values (Fig. 2) and nutrient stoichiometry of other compartments (Julian et al. 2019). Mean $\mathrm{RE}_{\mathrm{TP}}$ values observed at the inflow region, where P resources are especially high, were slightly lower with more variability than middle and outflow regions (Fig. 5), potentially suggesting some adaptation. We note that leaching of senesced litter may overestimate active resorption calculated here and in previous studies.

In addition to nutrient uptake, nutrient resorption itself can also contribute to overall stoichiometric homeostasis. In this study, we developed a concept based on first order dynamics similar to Menge et al. (2009) of how nutrient resorption can be incorporated into the stoichiometric homeostasis framework (Supplemental Material). By using equilibrium assumptions, we were able to distinguish contributions of uptake versus resorption to homeostasis (Fig. 6). In essence, we defined the effort put into homeostasis by the plant that determines changes in stoichiometry from differential uptake and from differential resorption. The definition of homeostasis is such that a value of zero indicates full homeostasis while a value of one suggests non-homeostasis. Effort towards homeostasis is therefore the complement of a homeostasis to one (Supplementary Information). The resulting calculations suggest that nutrient resorption contributes approximately $11 \%$ and $15 \%$ to stoichiometric homeostasis in EAV, when water and soil, respectively, are considered as the endmembers of nutrient supply 
429 (Fig. 6). In Fig.67 we indicated a positive effort towards maintaining homeostasis via an arrow

430 down, with the length of the arrow indicating the magnitude of the effort. Due to the limitation of

431 the data collected, we were unable to determine resorption homeostasis for SAV. Despite this

432 limitation, given the resorption dynamics observed in EAV, it is possible that resorption

433 homeostasis by SAV would be similar, contributing slightly to overall total homeostasis.

434 Despite some shortcomings of this study, the data allow us to evaluate homeostasic behavior in

435 sub-tropical treatment wetland systems. As noted above, it is not clear to what degree the

436 vegetation uses water versus soil as the main nutrient resource, generally it is assumed that EAV

437 mine nutrients from the soil (via soil porewater) and SAV take up nutrients from the water

438 column and modify the chemical environment to facilitate abiotic mineralization. It is possible

439 that one nutrient is preferably obtained from the water column, and the other from the soil. Given

440 the higher $\mathrm{N}: \mathrm{P}$ in the soil relative to the water column, it would be opportune for plants to

441 acquire $\mathrm{N}$ from the soil, while obtaining $\mathrm{P}$ from the water column. However, this inference may

442 be complicated by the fact that vegetation is specifically mining soil $\mathrm{P}$, depleting soil $\mathrm{P}$ storages

443 and therefore increasing the N:P ratio in the soil. Given our data, it is not clear to what degree $\mathrm{N}$

444 or $\mathrm{P}$ are accessible for plant uptake. Along the FW, the proportion of inorganic (rapidly taken up)

445 versus total nutrients varies in both the soil and water column (UF-WBL 2017). In the soil, the

446 majority of nutrients could be in a mineral form (predominately Ca-P minerals) and therefore not

447 as accessible to plants. Therefore, our calculation of homeostasis implicitly assumes that $\mathrm{N}$ and $\mathrm{P}$

448 were mineralized according to their total nutrient ratio. While not studied here, soil microbial

449 interactions within the soil relative to ambient pool of nutrients could also influence site-specific

450 nutrient dynamics along the FW (Wright and Reddy 2001; Corstanje et al. 2007). Inorganic

451 nutrient addition experiments targeting soil and water column specifically, and perhaps at 
452 various levels and ratios, would further create a more nuanced picture with respect to

453 homeostasis and preferential uptake pathways. Additionally, evaluation of SAV resorption and

454 resorption specific to other plant parts including plant rhizomes (i.e. plant roots) would also fill

455 knowledge gaps and allow better understanding of homeostasis due to resource partitioning

456 within wetland macrophytes. Nevertheless, treatment wetlands are useful systems that can be

457 used to study stoichiometric homeostasis as they present a wide nutrient gradient with large

458 variability in nutrient loading from inflow to the outflow.

461 This study suggests that vegetation within treatment wetlands maintains a relatively constant

462 uptake efficiencies for nitrogen and phosphorus as indicated by the non-homeostatic relationship

463 between foliar and active reservoirs. Thus, tissue nutrient concentrations and nutrient

464 concentrations of the ambient environment scale with each other to some degree. In this study,

465 we developed a framework to link nutrient resorption to the homeostasis concept and found that

466 resorption efforts can alleviate nutrient imbalances in the resource pools, although the resource

467 pool (water or soil) cannot be clearly identified. However, the strongly non-homeostatic behavior

468 of EAV with respect to soil resources requires further attention and we speculate that a lowering

469 of the N:P ratio in the resource pool will lead to storage of $\mathrm{P}$ in increasingly plant-inaccessible

470 compounds. 
473 We would like to thank SFWMD and UF Wetland Biogeochemistry Laboratory staff members

474 for providing the data used in this analysis. We would also like to thank Mark Brenner, Sue

475 Newman, Odi Villapando, Tom James, Jim Elser and the anonymous peer reviewer(s) and

476 editor(s) for their efforts and constructive review of this manuscript.

477

478 Conflict of Interest Statement

479 The authors declare that they have no conflict of interest.

$480 \quad$ Funding

481 Financial support for sample collection and analysis was provided by the South Florida Water

482 Management District (Contract \#4600003031).

\section{Authors' Contributions}

484 PJ performed data analyses including necessary calculations and statistical analyses and wrote 485 the manuscript. SG developed the expanded homeostasis framework, contributed to data 486 interpretation and writing. RKB and TZO were involved with data collection and writing. ALW 487 assisted with writing. JK was involved in data collection. All authors read and approved the final 488 manuscript.

$489 \quad$ References

490 Aerts R (1996) Nutrient Resorption from Senescing Leaves of Perennials: Are there General $491 \quad$ Patterns? Journal of Ecology 84:597-608. doi: 10.2307/2261481

492 Aerts R, Chapin FS (1999) The mineral nutrition of wild plants revisited: a re-evaluation of 493 processes and patterns. Advances in ecological research 30:1-67 
Boyer MLH, Wheeler BD (1989) Vegetation Patterns in Spring-Fed Calcareous Fens: Calcite Precipitation and Constraints on Fertility. Journal of Ecology 77:597-609. doi: $10.2307 / 2260772$

Brix H (2003) Plants used in constructed wetlands and their functions. In: Dias V, Vymazel J (eds) 1st International Seminar on the use of Aquatic Macrophytes for Wastewater Treatment in Constructed Wetlands. Lisbon, Portugal

Bruland GL, Osborne TZ, Reddy KR, et al (2007) Recent Changes in Soil Total Phosphorus in the Everglades: Water Conservation Area 3. Environmental Monitoring and Assessment 129:379-395. doi: 10.1007/s10661-006-9371-x

Chapin III FS, Schulze E-D, Mooney HA (1990) The Ecology and Economics of Storage in Plants. Annual Review of Ecology and Systematics 21:423-447

Chen H, Ivanoff D, Pietro K (2015) Long-term phosphorus removal in the Everglades stormwater treatment areas of South Florida in the United States. Ecological Engineering 79:158-168. doi: 10.1016/j.ecoleng.2014.12.012

Chimney MJ, Pietro KC (2006) Decomposition of macrophyte litter in a subtropical constructed wetland in south Florida (USA). Ecological Engineering 27:301-321. doi: 10.1016/j.ecoleng.2006.05.016

Corstanje R, Reddy KR, Prenger JP, et al (2007) Soil microbial eco-physiological response to nutrient enrichment in a sub-tropical wetland. Ecological Indicators 7:277-289. doi: 10.1016/j.ecolind.2006.02.002

Craft CB, Vymazal J, Richardson CJ (1995) Response of everglades plant communities to nitrogen and phosphorus additions. Wetlands 15:258-271. doi: 10.1007/BF03160706

De Deyn GB, Cornelissen JHC, Bardgett RD (2008) Plant functional traits and soil carbon sequestration in contrasting biomes. Ecology Letters 11:516-531. doi: 10.1111/j.14610248.2008.01164.x

DeBusk TA, Kharbanda M, Jackson SD, et al (2011) Water, vegetation and sediment gradients in submerged aquatic vegetation mesocosms used for low-level phosphorus removal. Science of The Total Environment 409:5046-5056. doi: 10.1016/j.scitotenv.2011.08.038

Demers JD, Driscoll CT, Fahey TJ, Yavitt JB (2007) Mercury cycling in litter and soil in different forest types in the adirondack region, new york, usa. Ecological Applications 17:1341-1351. doi: 10.1890/06-1697.1

Dhote S, Dixit S (2009) Water quality improvement through macrophytes-a review. Environmental Monitoring and Assessment 152:149-153. doi: 10.1007/s10661-0080303-9 
Dierberg FE, DeBusk TA, Jackson SD, et al (2002) Submerged aquatic vegetation-based treatment wetlands for removing phosphorus from agricultural runoff: response to hydraulic and nutrient loading. Water research 36:1409-1422

Dinno A (2015) Dunn's test of multiple comparisons using rank sums. CRAN R-Project

Duarte CM (1992) Nutrient concentration of aquatic plants: Patterns across species. Limnol Oceanogr 37:882-889. doi: 10.4319/1o.1992.37.4.0882

Elser JJ, Fagan WF, Denno RF, et al (2000) Nutritional constraints in terrestrial and freshwater food webs. Nature 408:578

Elser JJ, Fagan WF, Kerkhoff AJ, et al (2010) Biological stoichiometry of plant production: metabolism, scaling and ecological response to global change. New Phytologist 186:593608. doi: 10.1111/j.1469-8137.2010.03214.x

Feijoó C, Leggieri L, Ocón C, et al (2014) Stoichiometric homeostasis in the food web of a chronically nutrient-rich stream. Freshwater Science 33:820-831. doi: 10.1086/677056

Fernández-Aláez M, Fernández-Aláez C, Bécares E (1999) Nutrient content in macrophytes in Spanish shallow lakes. Hydrobiologia 408:317-326

Filipiak M (2016) Pollen Stoichiometry May Influence Detrital Terrestrial and Aquatic Food Webs. Front Ecol Evol 4:. doi: 10.3389/fevo.2016.00138

Filipiak M, Weiner J (2014) How to Make a Beetle Out of Wood: Multi-Elemental Stoichiometry of Wood Decay, Xylophagy and Fungivory. PLOS ONE 9:e115104. doi: 10.1371/journal.pone.0115104

Filipiak M, Weiner J (2017) Nutritional dynamics during the development of xylophagous beetles related to changes in the stoichiometry of 11 elements: Stoichiometry of xylophage development. Physiological Entomology 42:73-84. doi: 10.1111/phen.12168

Frost PC, Evans-White MA, Finkel ZV, et al (2005) Are you what you eat? Physiological constraints on organismal stoichiometry in an elementally imbalanced world. Oikos 109:18-28. doi: 10.1111/j.0030-1299.2005.14049.x

Gu Q, Zamin TJ, Grogan P (2017) Stoichiometric homeostasis: a test to predict tundra vascular plant species and community-level responses to climate change. Arctic Science 1-14. doi: 10.1139/as-2016-0032

Güsewell S (2004) N $\square$ : P ratios in terrestrial plants: variation and functional significance. New Phytologist 164:243-266. doi: 10.1111/j.1469-8137.2004.01192.x

Güsewell S, Koerselman W (2002) Variation in nitrogen and phosphorus concentrations of wetland plants. Perspectives in Plant Ecology, Evolution and Systematics 5:37-61. doi: 10.1078/1433-8319-0000022 
Güsewell S, Koerselman W, Verhoeven JTA (2003) Biomass n:p ratios as indicators of nutrient limitation for plant populations in wetlands. Ecological Applications 13:372-384. doi: 10.1890/1051-0761(2003)013[0372:BNRAIO]2.0.CO;2

Julian P, Gerber S, Bhomia RK, et al (2019) Evaluation of nutrient stoichiometric relationships among ecosystem compartments of a subtropical treatment wetland. Do we have "Redfield wetlands"? Ecol Process 8:20. doi: 10.1186/s13717-019-0172-x

Julian P, Gerber S, Wright AL, et al (2017) Carbon pool trends and dynamics within a subtropical peatland during long-term restoration. Ecol Process 6:43-57. doi: 10.1186/s13717-017-0110-8

Juston J, DeBusk TA (2006) Phosphorus mass load and outflow concentration relationships in stormwater treatment areas for Everglades restoration. Ecological Engineering 26:206223. doi: 10.1016/j.ecoleng.2005.09.011

Kadlec RH, Wallace SD (2009) Treatment wetlands. CRC Press, Boca Raton, FL

Killingbeck KT (1996) Nutrients in Senesced Leaves: Keys to the Search for Potential Resorption and Resorption Proficiency. Ecology 77:1716-1727. doi: 10.2307/2265777

King J, Zweig C (2016) P Flux Vegetation Assessments-Submerged Aquatic Vegetation (SAV) Biomass Sampling and Analysis September 2016. South Florida Water Management District, West Palm Beach, FL

Koerselman W, Meuleman AFM (1996) The Vegetation N:P Ratio: a New Tool to Detect the Nature of Nutrient Limitation. The Journal of Applied Ecology 33:1441. doi: $10.2307 / 2404783$

Komsta L (2013) Median-Based Linear Models. CRAN R-Project

Makino W, Cotner JB, Sterner RW, Elser JJ (2003) Are Bacteria More Like Plants or Animals? Growth Rate and Resource Dependence of Bacterial C: N: P Stoichiometry. Functional Ecology 17:121-130

McGroddy ME, Daufresne T, Hedin LO (2004) Scaling of C:N:P stoichiometry in forests worldwide: implications of terrestrial redfield-type ratios. Ecology 85:2390-2401. doi: 10.1890/03-0351

Menge DNL, Pacala SW, Hedin LO (2009) Emergence and Maintenance of Nutrient Limitation over Multiple Timescales in Terrestrial Ecosystems. The American Naturalist 173:164175. doi: 10.1086/595749

Miao S (2004) Rhizome growth and nutrient resorption: mechanisms underlying the replacement of two clonal species in Florida Everglades. Aquatic Botany 78:55-66. doi: 10.1016/j.aquabot.2003.09.001 
Miao SL, Zou CB (2012) Effects of inundation on growth and nutrient allocation of six major macrophytes in the Florida Everglades. Ecological Engineering 42:10-18. doi: 10.1016/j.ecoleng.2012.01.009

Newman S, Osborne TZ, Hagerthey SE, et al (2017) Drivers of landscape evolution: multiple regimes and their influence on carbon sequestration in a sub-tropical peatland. Ecol Monogr 87:578-599. doi: 10.1002/ecm.1269

Osborne TZ, Bruland GL, Newman S, et al (2011) Spatial distributions and eco-partitioning of soil biogeochemical properties in the Everglades National Park. Environmental Monitoring and Assessment 183:395-408. doi: 10.1007/s10661-011-1928-7

Peng H, Chen Y, Yan Z, Han W (2016) Stage-dependent stoichiometric homeostasis and responses of nutrient resorption in Amaranthus mangostanus to nitrogen and phosphorus addition. Scientific Reports 6:. doi: 10.1038/srep37219

Persson J, Fink P, Goto A, et al (2010) To be or not to be what you eat: regulation of stoichiometric homeostasis among autotrophs and heterotrophs. Oikos 119:741-751. doi: 10.1111/j.1600-0706.2009.18545.x

Rattray MR, Howard-Williams C, Brown JMA (1991) Sediment and water as sources of nitrogen and phosphorus for submerged rooted aquatic macrophytes. Aquatic Botany 40:225-237. doi: 10.1016/0304-3770(91)90060-I

Reddy KR, DeLaune RD (2008) Biogeochemistry of wetlands: science and applications. CRC Press, Boca Raton, FL

Reddy KR, Kadlec RH, Flaig E, Gale PM (1999) Phosphorus Retention in Streams and Wetlands: A Review. Critical Reviews in Environmental Science and Technology 29:83146. doi: 10.1080/10643389991259182

Redfield AC (1958) The biological control of chemical factors in the environment. American Scientist 46:230A-221

Reed SC, Townsend AR, Davidson EA, Cleveland CC (2012) Stoichiometric patterns in foliar nutrient resorption across multiple scales. New Phytologist 196:173-180. doi: 10.1111/j.1469-8137.2012.04249.x

Rejmánková E (2005) Nutrient resorption in wetland macrophytes: comparison across several regions of different nutrient status. New Phytologist 167:471-482. doi: 10.1111/j.14698137.2005.01449.x

Rejmánková E, Macek P, Epps K (2008) Wetland ecosystem changes after three years of phosphorus addition. Wetlands 28:914-927. doi: 10.1672/07-150.1

Rejmánková E, Snyder JM (2008) Emergent macrophytes in phosphorus limited marshes: do phosphorus usage strategies change after nutrient addition? Plant Soil 313:141-153. doi: 10.1007/s11104-008-9687-0 
Richardson CJ, Marshall PE (1986) Processes Controlling Movement, Storage, and Export of Phosphorus in a Fen Peatland. Ecological Monographs 56:280-302. doi: $10.2307 / 1942548$

Rivas-Ubach A, Sardans J, Pérez-Trujillo M, et al (2012) Strong relationship between elemental stoichiometry and metabolome in plants. PNAS 109:4181-4186. doi: 10.1073/pnas.1116092109

Sardans J, Rivas-Ubach A, Peñuelas J (2012) The C:N:P stoichiometry of organisms and ecosystems in a changing world: A review and perspectives. Perspectives in Plant Ecology, Evolution and Systematics 14:33-47. doi: 10.1016/j.ppees.2011.08.002

Shaver GR, Melillo JM (1984) Nutrient Budgets of Marsh Plants: Efficiency Concepts and Relation to Availability. Ecology 65:1491-1510. doi: 10.2307/1939129

Sistla SA, Appling AP, Lewandowska AM, et al (2015) Stoichiometric flexibility in response to fertilization along gradients of environmental and organismal nutrient richness. Oikos 124:949-959. doi: 10.1111/oik.02385

Sistla SA, Schimel JP (2012) Stoichiometric flexibility as a regulator of carbon and nutrient cycling in terrestrial ecosystems under change. The New Phytologist 196:68-78

Small GE, Helton AM, Kazanci C (2009) Can consumer stoichiometric regulation control nutrient spiraling in streams? Journal of the North American Benthological Society 28:747-765. doi: 10.1899/08-099.1

Smalley GW, Coats DW, Stoecker DK (2003) Feeding in the mixotrophic dinoflagellate Ceratium furca is influenced by intracellular nutrient concentrations. Marine Ecology Progress Series 262:137-151. doi: 10.3354/meps262137

South Florida Water Management District (2013) Restoration Strategies Regional Water Quality Plan: Science Plan for the Everglades Stormwater Treatment Areas. South Florida Water Management District, West Palm Beach, FL

Sterner, Clasen, Lampert, Weisse (1998) Carbon:phosphorus stoichiometry and food chain production. Ecology Letters 1:146-150. doi: 10.1046/j.1461-0248.1998.00030.x

Sterner RW, Elser JJ (2002) Ecological Stoichiometry: The Biology of Elements from Molecules to the Biosphere. Princeton University Press

UF-WBL (2017) Evaluation of Soil Biogeochemical Properties Influencing Phosphorus Flux in the Everglades Stormwater Treatment areas: 2016-2017 Annual Report. University of Florida, Gainesville, FL

Van Heerwaarden LM, Toet S, Aerts R (2003) Current measures of nutrient resorption efficiency lead to a substantial underestimation of real resorption efficiency: facts and solutions. Oikos 101:664-669. doi: 10.1034/j.1600-0706.2003.12351.x 
Villapando O, King J (2018) Appendix 5C-3: Evaluation of Phosphorus Sources, Forms, Flux, and Transformation Processes in the Stormwater Treatment Areas. In: 2018 South Florida Environmental Report. South Florida Water Management District, West Palm Beach, FL

Wright AL, Reddy KR (2001) Phosphorus loading effects on extracellular enzyme activity in Everglades wetland soils. Soil Science Society of America Journal 65:588-595

Yu Q, Elser JJ, He N, et al (2011) Stoichiometric homeostasis of vascular plants in the Inner Mongolia grassland. Oecologia 166:1-10. doi: 10.1007/s00442-010-1902-z

Zar JH (2010) Biostatistical Analysis, 15th edn. Prentice Hall

\section{Figures and Tables}

Figure 1. Surface water, soil and vegetation monitoring locations within Everglades Stormwater Treatment Area-2 cells 1 (right) and 3 (left). Cell 1 is predominately emergent vegetation and Cell 3 is predominately submerged aquatic vegetation. Operationally these cells are identified as flow-way 1 and 3, respectively.

Figure 2. Distribution of plant foliar stoichiometric relationships within flow-way (FW) 1 and FW 3 of Stormwater Treatment Area-2. Left and middle panels are histogram representations of each respective stoichiometric relationship. The right panel is a cumulative distribution of stoichiometric relationship for each FW.

Figure 3. Resource (Top: Soil and Bottom: Surface Water) and vegetation nitrogen to phosphorus molar ratio $(\mathrm{N}: \mathrm{P})$ with Theil-Sen single median linear model $\pm 95 \%$ confidence interval for each vegetation type. Note both axes are log-scale.

Figure 4. Homeostasis coefficient $\left(1 / \mathrm{H}_{\mathrm{T}}\right)$ and $95 \%$ confidence interval with respect to soil and surface water resources for emergent aquatic vegetation and submerged aquatic vegetation (EAV and SAV, respectively) vegetation communities and flow-way. Dashed line indicates the homeostasis/non-homeostasis threshold (0.5) and the theoretical maximum $1 / \mathrm{H}_{\mathrm{T}}$ (i.e. 1.0).

Figure 5. Strip plot of $(A)$ total phosphorus resorption efficiency $\left(\mathrm{RE}_{\mathrm{TP}}\right)$ and $(\mathrm{B})$ total nitrogen resorption efficiency $\left(\mathrm{RE}_{\mathrm{TN}}\right)$ of cattail within Stormwater Treatment Area-2 flow-way 1. Raw data are represented by grey points, while mean \pm standard error are represented by black points.

Figure 6. Median total homeostasis coefficient $\left(1 / H_{T}\right)$ for emergent aquatic vegetation (EAV; FW1) with effort associated with maintaining total $\left(H_{T}\right.$; red arrows), resorptive $\left(H_{R E}\right.$; blue arrows) and uptake $\left(H_{u}\right.$; black arrows). A downward arrow indicates the effort into maintaining homeostasis, representing the 1-1/H expression in Eq. 5. 


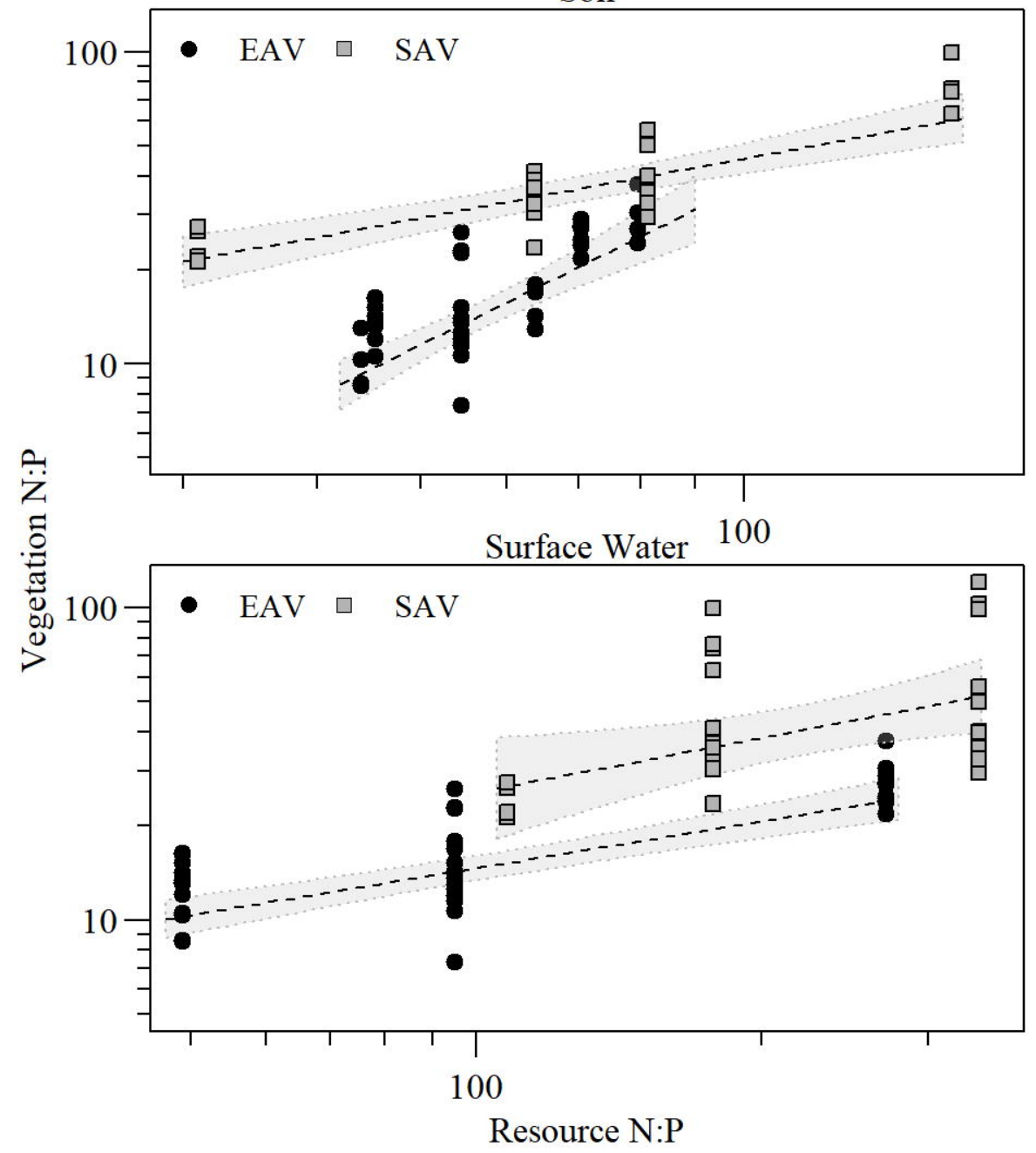




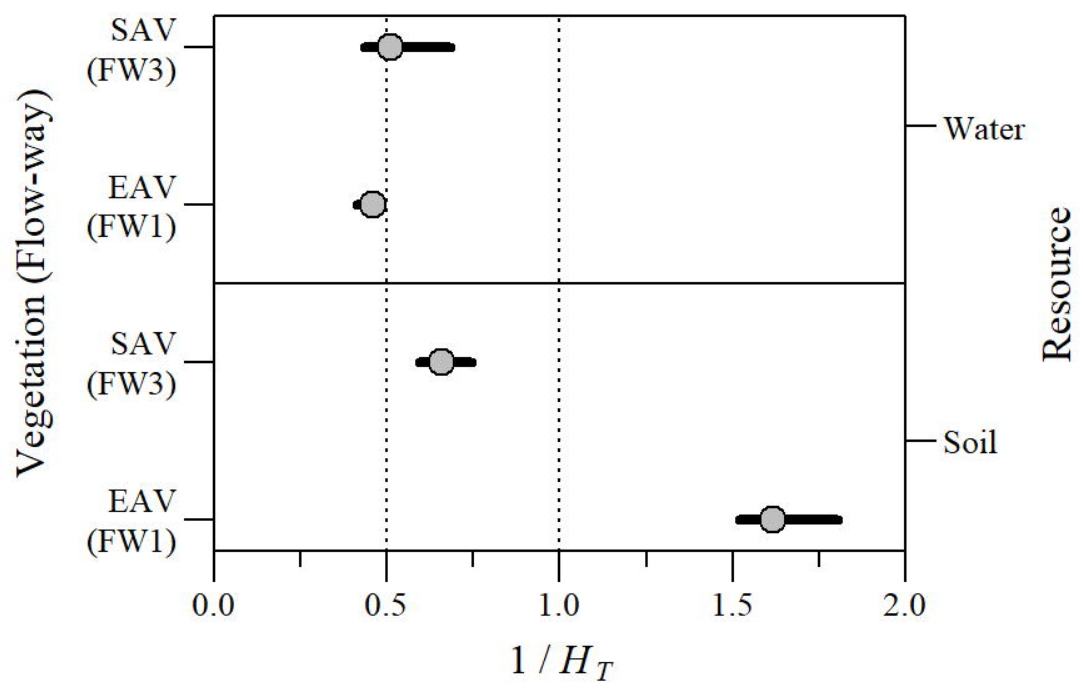



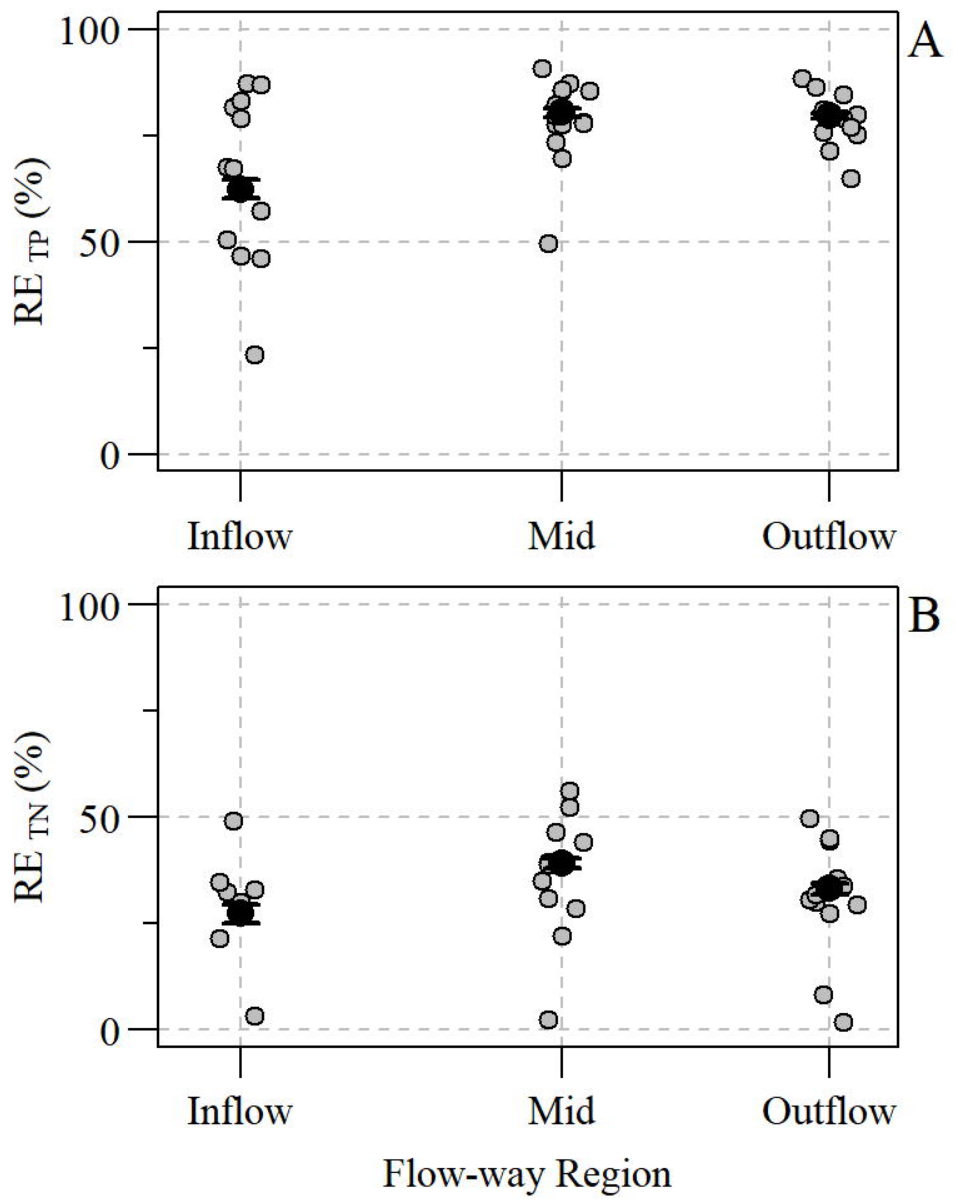


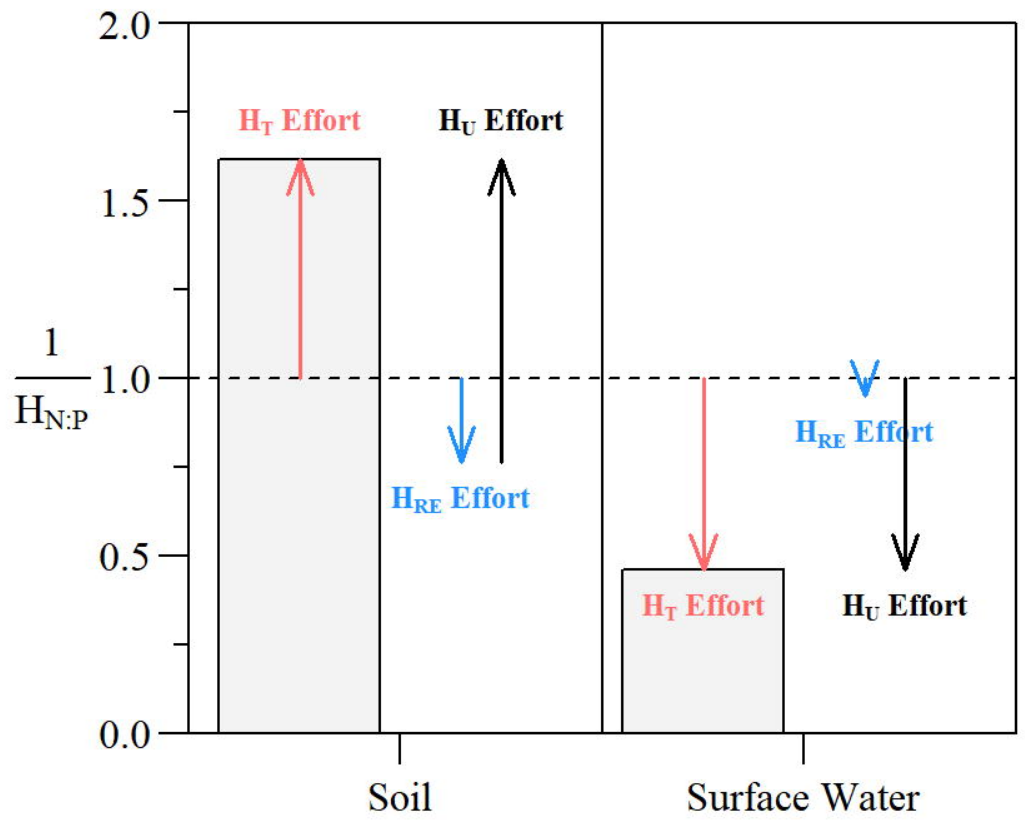

Compartment 
Table 1. Summary statistics for variables and matrices used in this study of samples collected along the flow-way (FW) 1 and 3 transect within Stormwater Treatment Area-2. Summary statistics include mean, standard error (SE), sample size (N), range, and coefficient of variation (CV). Matrices include surface water, recently accreted soil and live aboveground biomass of sampled vegetation Note: Dissolved Organic Carbon = DOC; Total Phosphorus = TP; Total Nitrogen = TN; Total Carbon - TC; Loss-onignition $=\mathrm{LOI}$; Calcium $=\mathrm{Ca}$.

\begin{tabular}{|c|c|c|c|c|c|c|c|}
\hline \multirow[b]{2}{*}{ Matrix } & \multirow[b]{2}{*}{ Parameter (Units) } & \multicolumn{3}{|c|}{ Flow-way 1} & \multicolumn{3}{|c|}{ Flow-way 3} \\
\hline & & Mean \pm SE $(\mathbf{N})$ & Range & $\mathrm{CV}$ & $\operatorname{Mean} \pm \operatorname{SE}(\mathbf{N})$ & Range & CV \\
\hline \multirow[t]{6}{*}{ Surface Water } & $\mathrm{DOC}(\mathrm{mM})$ & $2.23 \pm 0.05(109)$ & $1.26-3.31$ & 23 & $2.57 \pm 0.02(177)$ & $1.54-3.33$ & 10 \\
\hline & $\mathrm{TP}(\mathrm{mM})$ & $0.0021 \pm 0.0002$ & $0.0003-0.012$ & 116 & $0.0011 \pm 0.00008$ (169) & $0.0002-0.0094$ & 91 \\
\hline & $\mathrm{TN}(\mathrm{mM})$ & $0.12 \pm 0.003(107)$ & $0.06-0.22$ & 26 & $0.15 \pm 0.001(177)$ & $0.11-0.30$ & 14 \\
\hline & DOC:TP (molar) & $2,649 \pm 220(95)$ & $216-9,532$ & 81 & $3,753 \pm 187(169)$ & $290-1,461$ & 65 \\
\hline & DOC:TN (molar) & $18.9 \pm 0.21(101)$ & $12.8-24.0$ & 11 & $16.8 \pm 0.12(177)$ & $9.30-19.1$ & 10 \\
\hline & TN:TP (molar) & $137.6 \pm 11.3(93)$ & $15.5-410.3$ & 80 & $216.0 \pm 9.89(169)$ & $31.2-788.7$ & 90 \\
\hline \multirow[t]{8}{*}{ Soil } & LOI $(\%)$ & $79.5 \pm 2.2(27)$ & $18.6-91.0$ & 14 & $54.7 \pm 4.7(25)$ & $20.3-83.9$ & 43 \\
\hline & $\mathrm{TC}\left(\mathrm{mM} \mathrm{kg}^{-1}\right)$ & $36,051 \pm 963(27)$ & $24,145-41,962$ & 14 & $29,423 \pm 1,895(25)$ & $15,320-40,797$ & 32 \\
\hline & $\mathrm{TP}\left(\mathrm{mM} \mathrm{kg}^{-1}\right)$ & $27.6 \pm 2.1(27)$ & $11.1-43.8$ & 40 & $15.8 \pm 1.05(25)$ & $11.6-29.0$ & 33 \\
\hline & $\mathrm{TN}\left(\mathrm{mM} \mathrm{kg}^{-1}\right)$ & $2,037 \pm 52(27)$ & $1,421-2,413$ & 13 & $1,451 \pm 110.7(25)$ & $368.3-2,213$ & 38 \\
\hline & TC:TP (molar) & $1,669 \pm 190(27)$ & $671-3,511$ & 59 & $2,104 \pm 192.2(25)$ & $557.1-3,520$ & 46 \\
\hline & TC:TN (molar) & $17.7 \pm 0.3(27)$ & $14.9-21.1$ & 7 & $20.9 \pm 0.4(25)$ & $17.9-24.0$ & 9 \\
\hline & TN:TP (molar) & $92.2 \pm 9.7(27)$ & $39.5-192.4$ & 55 & $104.7 \pm 10.6(25)$ & $23.5-187.3$ & 51 \\
\hline & $\mathrm{Ca}\left(\mathrm{mM} \mathrm{kg}^{-1}\right)$ & $1,737 \pm 206(27)$ & $649-4,465$ & 62 & $3,987 \pm 472.0(25)$ & $978.7-7,637$ & 59 \\
\hline \multirow[t]{6}{*}{ Vegetation } & $\mathrm{TC}\left(\mathrm{mM} \mathrm{kg}^{-1}\right)$ & $35,347 \pm 152(39)$ & $32,305-38,174$ & 3 & $22,583 \pm 711.3(33)$ & $15,486-29,932$ & 18 \\
\hline & $\mathrm{TP}\left(\mathrm{mM} \mathrm{kg}^{-1}\right)$ & $43.8 \pm 3.4(39)$ & $11.6-97.4$ & 49 & $26.3 \pm 5.9(33)$ & $6.78-109.1$ & 72 \\
\hline & $\mathrm{TN}\left(\mathrm{mM} \mathrm{kg}^{-1}\right)$ & $672.5 \pm 34.9(39)$ & $435.5-1,756$ & 32 & $1,606 \pm 137.7(33)$ & $671.1-3,476.9$ & 49 \\
\hline & TC:TP (molar) & $1,055 \pm 96.4(39)$ & $361.5-3,110$ & 57 & $845.3 \pm 116.3(33)$ & $237.4-2,486.7$ & 79 \\
\hline & TC:TN (molar) & $56.0 \pm 2.0(39)$ & $19.3-82.8$ & 22 & $16.1 \pm 0.84(33)$ & $7.50-23.7$ & 30 \\
\hline & TN:TP (molar) & $18.2 \pm 1.2(39)$ & $7.67-37.6$ & 41 & $48.1 \pm 4.81(33)$ & $21.3-120.4$ & 57 \\
\hline
\end{tabular}


Table 2. Overall log-log median based model statistics of vegetation nitrogen to phosphorus (N:P) versus soil and surface water resource pools between emergent and submerged aquatic vegetation (EAV and SAV, respectively) communities within Stormwater Treatment Area 2 Flow-way 1 and Flow-way 3, respectively.

\begin{tabular}{lcccccccr}
\hline Resource & Community & $\begin{array}{c}\text { Slope } \\
\left(1 / \mathrm{H}_{\mathrm{T}}\right)\end{array}$ & $\begin{array}{c}\text { Intercept } \\
(\mathrm{c} \text {-value })\end{array}$ & $\mathrm{R}^{2}$ & $\begin{array}{c}\text { Median } \\
\text { Absolute } \\
\text { Deviation }\end{array}$ & V-statistic & df & $\rho$-value \\
\hline Soil & EAV & 1.62 & -3.70 & 0.61 & 1.50 & 168032 & 37 & $<0.01$ \\
& SAV & 0.66 & 0.84 & 0.72 & 0.47 & 19947 & 22 & $<0.01$ \\
\multirow{3}{*}{ Water Column } & EAV & 0.46 & 0.70 & 0.60 & 0.34 & 116683 & 37 & $<0.01$ \\
& SAV & 0.51 & 0.93 & 0.17 & 0.94 & 23162 & 26 & $<0.01$ \\
\hline
\end{tabular}


Table 3. Resorption efficiency summary statistics for emergent aquatic vegetation species collected within Stormwater Treatment Area 2, FW 1. Total Phosphorus Resorption efficiency $\left(\mathrm{RE}_{\mathrm{TP}}\right)$ calculated with equation 1, using both living and senescent living aboveground biomass. Summary statistics include mean, standard error, range, coefficient of variation and sample size (N).

Total Phosphorus

Total Nitrogen

\begin{tabular}{|c|c|c|c|c|c|c|c|c|}
\hline Species & $\begin{array}{c}\text { Mean } \pm \mathrm{SE} \\
(\%)\end{array}$ & $\begin{array}{c}\text { Range } \\
(\%)\end{array}$ & $\begin{array}{c}\text { Coefficient } \\
\text { of } \\
\text { Variation }\end{array}$ & $\mathbf{N}$ & $\begin{array}{c}\text { Mean } \pm \text { SE } \\
(\%)\end{array}$ & $\begin{array}{c}\text { Range } \\
(\%)\end{array}$ & $\begin{array}{c}\text { Coefficient } \\
\text { of } \\
\text { Variation }\end{array}$ & $\mathbf{N}$ \\
\hline $\begin{array}{l}\text { Typha domingensis Pers. } \\
\text { (cattail) }\end{array}$ & $74 \pm 2$ & $24-91$ & 20.1 & 36 & $33 \pm 2$ & $1.8-56$ & 39.8 & 29 \\
\hline $\begin{array}{l}\text { Nymphaea odorata Aiton } \\
\text { (water lily) }\end{array}$ & 70 & --- & --- & 1 & --- & --- & --- & -- \\
\hline $\begin{array}{l}\text { Cladium jamaicense Crantz } \\
\text { (sawgrass) }\end{array}$ & 77 & --- & --- & 1 & 2.3 & --- & --- & 1 \\
\hline
\end{tabular}

